Jurnal SEMAR Vol. 7 No. 2, 2018 hal. $38-50$

ISSN: 2302-3937 | Copyright (C LPPM Universitas Sebelas Maret

Homepage: https://jurnal.uns.ac.id/jurnal-semar

\title{
PEMBELAJARAN MODEL INTERAKTIF RAMAH ORANG TUA DAN GURU (PKM BA AISYIAH BULAKREJO II DAN TK DESA SIDOREJO 03)
}

\author{
Susi Endrawati ${ }^{1)}$, Trismianto Asmo Sutrisno ${ }^{2)}$ \\ 1) Program Studi D3 Farmasi, ${ }^{2}$ Program Studi D3 Rekam Medis dan Informasi \\ Kesehatan Poltekkes Bhakti Mulia Sukoharjo \\ e-mail: susiendrawati5@gmail.com
}

\begin{abstract}
Abstrak
Anak- anak adalah Anugerah Tuhan Yang Maha Esa, permata hati orang tua dan masa depan Bangsa. Orang tua berkewajiban membimbing, mendidik dan mengupayakan kesejahteraannya semaksimal mungkin. Sebagai bentuk bimbingan dan pendidikan yang diupayakan adalah pendidikan non formal di lingkungan keluarga dan formal di lingkungan sekolah. Orang tua berharap putra putrinya mendapatkan pendidikan yang baik dari guru-guru TK yang berkompeten. Pengabdian masyarakat ini dilakukan di dua lembaga mitra yaitu BA. Aisyiah Bulakrejo II dan TK Desa Sidorejo 03 yang berlokasi di wilayah kecamatan Sukoharjo.Tujuan pengabdian masyarakat ini, membantu lembaga sekolah meningkatkan keterampilan pedagogik guru-guru TK, supaya menjadi lebih berkualitas dalam menyampaikan materi proses belajar mengajar di kelas. Keterbatasan dana operasional yang sering dialami kedua lebaga TK, mengakibatkan masih kurang mencukupinya ketersediaan alat permainan, agar setara dengan jumlah anak didik Target yang sudah dicapai adalah pembuatan model interaktif pembelajaran, dengan 1) Melaksanakan workshop teknologi media ajar bagi guru- guru TK, 2) Melatih keterampilan guru dalam membuat APE bahan bekas, 3) Membuat media pemasaran APE dan media pembelajaran melalui website http://peragaedukatif.web.id/web/wp-login.php. Program ini mampu membuat kreativitas guru-guru TK dalam pembelajaran menjadi lebih menarik dan mudah dimengerti. Berkebangnya teknologi informatika memberi peluang bagi guru TK untuk dapat merancang dan membuat model pembelajaran interaktif multimedia.
\end{abstract}

Kata Kunci : Model Interaktif, Peraga Edukatif, Pembelajaran anak

\section{PENDAHULUAN}

Pendidikan anak usia taman kanak-kanak memegang peranan sangat penting pada pembentukan generasi penerus bangsa Indonesia di masa depan. Anak-anak usia di usia tersebut merupakan bagian dari sumber daya manusia yang memerlukan penanganan yang serius dan berkelanjutan oleh semua pihak yang mempunyai tanggung jawab bersama pada pembentukan generasi penerus yang berkualitas. Menurut Undang-undang RI nomor 35 tahun 2014, Orang tua berkewajiban dan bertanggung jawab untuk; 1) mengasuh, memelihara, mendidik, dan melindungi anak, 2) menumbuh kembangkan anak sesuai dengan kemampuan, bakat, dan minatnya, 3) memberikan pendidikan karakter dan penanaman nilai budi pekerti pada anak.Untuk memastikan mendapatkan generasi penerus yang berkualitas, diperlukan tindakan - tindakan nyata oleh pihak yang bergerak aktif dalam dunia pendidikan. 
Diusia taman-kanak, anak-anak perlu bimbingan, latihan dan pengarahan yang benar, supaya tidak menimbulkan apersepsi yang salah, pada pengalamanannya belajar. Chaplin, (1972) dalam Dictionary of Psychology, membatasi belajar dengan dua rumusan. Rumusan pertama, belajar adalah perolehan perubahan tingkah laku yang relatif menetap sebagai akibat latihan dan pengalaman. Rumusan kedua, belajar adalah proses memperoleh respon-respon sebagai akibat adanya latihan khusus.(Syah, 2012)

Gordon Dryden dan Jeanette Vos dalam bukunya The Learning Revolution, (diterjemahkan oleh Word Translation Service, 2002) menulis: 1) Menjelang kelahiran : kebanyakan anak memiliki 100 milyar sel otak aktif, dan mereka menjalin sekitar 50 triliun hubungan dengan sel otak lain dan bagian tubuh lain, 2) Dalam bulan-bulan awal: saat indra bayi bereaksi terhadap lingkungannya, dia mengembangkan hubungan "sinaptik" baru dengan kecepatan yang menakjubkan hingga 3 milyar perdetik, 3) Dalam 6 bulan pertama: bayi akan berbicara dengan menggunakan semua suara di semua bahasa dunia, namun dia kemudian akan belajar berbicara dengan cuma menggunakan suara dan kata-kata yang dia ambil dari lingkungan, khususnya dari orangtuanya. Otaknya akan membuang ketrampilan berbicara dalam bahasa yang tidak ia dengar, 4) Menjelang usia 8 bulan: otak bayi memiliki 1.000 triliun hubungan. Sesudah itu jumlah hubungan menurun kecuali jika dihadapkan pada rangsangan lewat semua indranya, 5) Menjelang usia sekitar 10 tahun, sekitar separo hubungan telah mati pada kebanyakan anak, namun masih meninggalkan sekitar 500 triliun yang akan bertahan sepanjang hayat. Khususnya tiga tahun pertama, dasar-dasar berpikir, bahasa, pandangan, tingkah laku, bakat dan karakteristik lain diletakkan.

Terkait dengan UU No 20 tahun 2003, tentang Sistem Pendidikan Nasional bahwasannya pemerataan kesempatan pendidikan, peningkatan mutu serta relevansi dan efisiensi manajemen pendidikan untuk menghadapi tantangan, sesuai dengan tututan perubahan kehidupan lokal, nasional, dan global, perlu dilakukan pembaharuan

pendidikan secara terencana, terarah, maka perguruan tinggi ikut bertanggung jawab membantu pemerintah menyiapkan tenaga - tenaga pendidik usia taman kanakkanak. Melaluikegiatan pengabdian masyarakat, juga berusaha ikut membantu mengatasi masalah- masalah utama tentang pendidikan anak yang muncul di masyarakat khususnya di lembaga pendidikan TK. Masyarakat dan pemerintah memberikan aplikasi positif pada pembentukan generasi penerus yang berkualitas. Tumbuh dan berkembangnya lembaga TK di tengah masyarakat ternyata juga harus diiringi oleh kesiapan para tenaga pendidiknya untuk memastikan proses pengembangan pembelajaran dari berbagai aspek berlangsung secara baik dan memenuhi standar pendidikan anak usia taman kanak-kanak. Dari data observasi dan investigasi di lapangan, ternyata tidak semudah yang dibayangkan. Berikut adalah Fakta penelusuran tim dilapangan pada dua lembaga TK yang bersedia menjadi mitra kerjasama kegiatan masyarakat, yatu BA Aisyiah Bulakrejo II dan TK Desa Sidorejo 03 Wilayah Kecamatan Sukoharjo.

BA Aisyiah Bulakrejo II berdiri sejak tahun 2005 (saat ini sudah 13 tahun), awalnya kegiatan belajar mengajar sekolah berada dalam lingkungan masjid, karena masjid direnovasi, maka kegiatan belajar mengajar pindah di salah satu rumah penduduk. sampai sekarang. Pada waktu pengusulan program BA Aisyiah Bulakrejo II dipimpin oleh bapak Suharno yang merangkap sebagai guru taman kanak-kanak di desa tersebut. Jumlah siswa tahun 2015/2016 ada 12 siswa terdiri dari 5 anak laki - laki dan 7 anak perempuan. Sedangkan pada tahun 2016/2017 ini jumlah siswa berjumlah 14 anak, terdiri dari 7 anak laki-laki dan 7 anak perempuan. Pada tahun 2017/2018 sekarang ini, 
Jurnal SEMAR Vol. 7 No. 2, 2018 hal. 38 - 50

ISSN: 2302-3937 | Copyright @ LPPM Universitas Sebelas Maret Homepage: https://jurnal.uns.ac.id/jurnal-semar

jumlah siswa mengalami penurunan menjadi 11 orang, 5 laki-laki dan 6 perempuan. Sekarang ini ada perubahan pengelola di BA Aisyiah Bulakrejo II, yang sekarang dipimpin oleh ibu Nuryati, S.Pd.I dan bapak Suharno beberapa waktu juga membantu. Kondisi BA Aisyiah Bulakrejo II ini cukup memprihatinkan dengan semua keterbatasan yang ada. Ruang kelas yang dimiliki sebanyak 1 ruang kelas yang digunakan untuk belajar bersama antara BA A dan BA B. Beberapa anak - anak TK yang dulu tidak memakai sepatu jika pergi ke sekolah, sekarang sudah bersepatu, hanya hari sabtu saja diijinkan memakai serandal, dahulu tidak memakai kursi, sekarang sudah ada kursi. Berikut ini adalah beberapa foto dokumentasi yang menggambarkan suasana kelas maupun lingkungan BA Aisyiah Bulakrejo II.

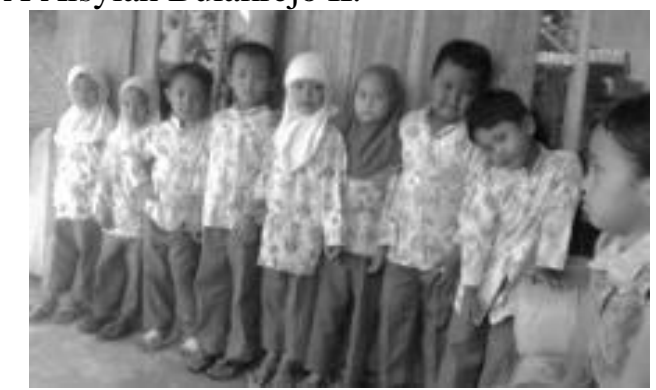

Gambar 1. Anak-anak sebelum pelajaran Dimulai

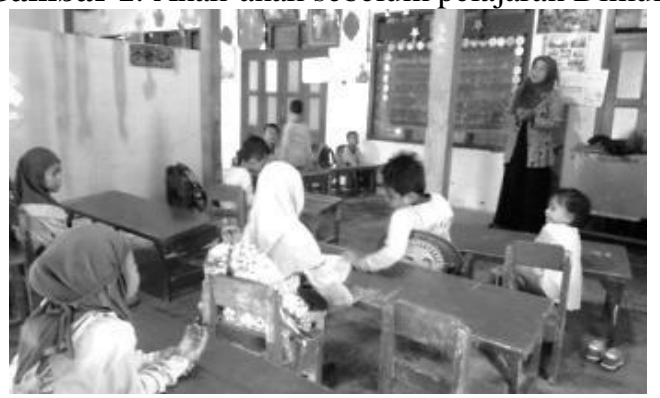

Gambar 2.Silahturahmi kelolosan program

Sedangkan TK Desa Sidorejo 03 berdiri pada tahun 1984 (saat ini berdiri sudah 34 tahun) dengan jumlah tenaga guru saat ini sebanyak 3 orang sudah termasuk kepala sekolahnya. Saat ini yang menjabat sebagai kepala sekolah adalah ibu Suyatmi, S.Pd. Jumlah siswa yang tercatat pada tahun 2015/2016 adalah 18 anak, terdiri dari 7 anak laki - laki dan 11 anak perempuan. Sedangkan tahun 2016/2017 jumlah siswa 16 anak, terdiri dari 8 laki-laki dan 8 perempuan. Jumlah siswa ini mengalami penurunan dari tahun sebelumnya yaitu 20 siswa. Pada tahun 2017/2018 mengalami kenaikan kjumlah siswa menjadi 19, terdiri dari 10 laki-laki dan 9 perempuan. TK ini memiliki bangunan sekolah hak milik sendiri dari hibah pemerintah desa Sidorejo, mempunyai 2 ruang kelas sebagai ruang belajar anak - anak. Berikut ini adalah beberapa foto dokumentasi yang menggambarkan suasana keadaan kelas maupun lingkungan di TK Desa sidorejo 03. 
Jurnal SEMAR Vol. 7 No. 2, 2018 hal. $38-50$

ISSN: 2302-3937 | Copyright @ LPPM Universitas Sebelas Maret Homepage: https://jurnal.uns.ac.id/jurnal-semar

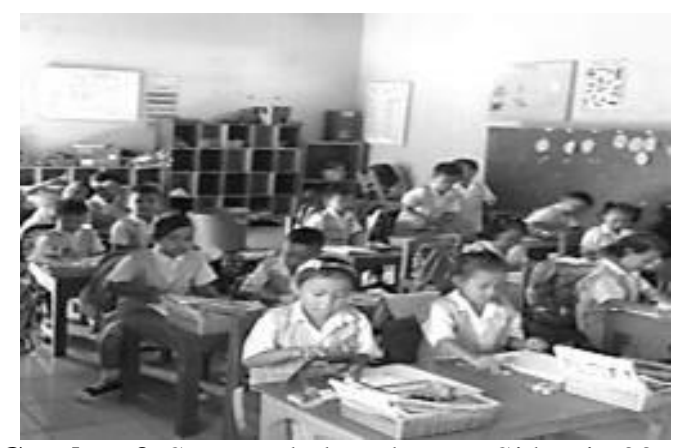

Gambar 3. Suasana kelas Tk Desa Sidorejo 03

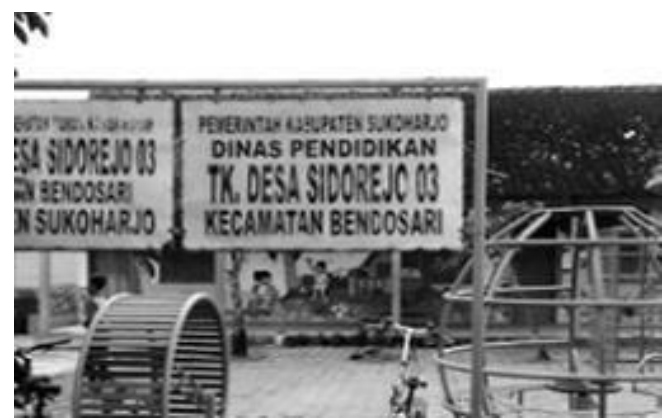

Gambar 4. Halaman sekolah TK Desa Sidorejo 03

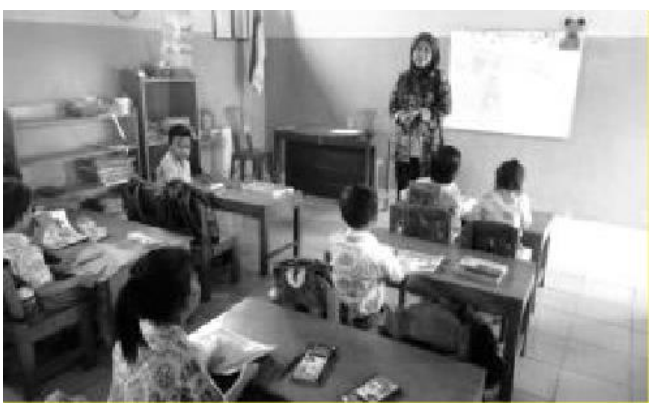

Gambar 5. Penjelasan tim untuk lomba Menggambar 
Jurnal SEMAR Vol. 7 No. 2, 2018 hal. $38-50$

ISSN: 2302-3937 | Copyright @ LPPM Universitas Sebelas Maret Homepage: https://jurnal.uns.ac.id/jurnal-semar

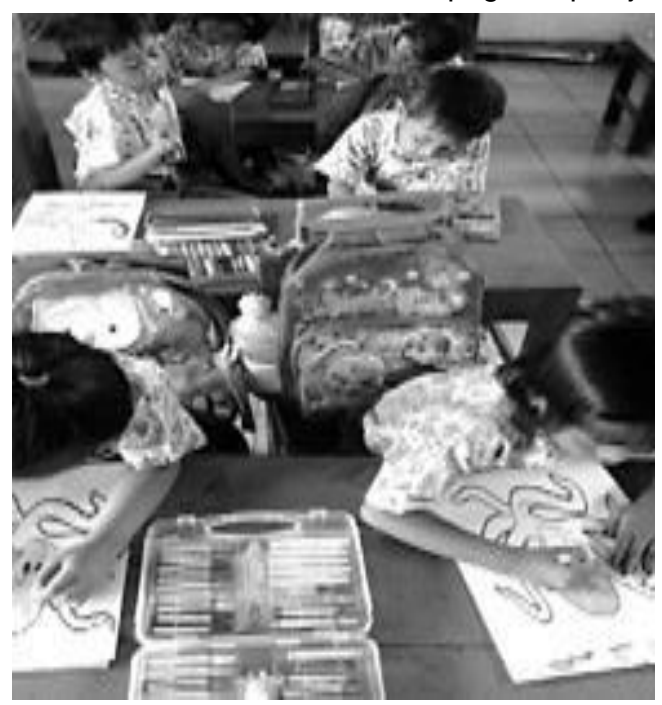

Gambar 6. Lomba mewarnai Sekolah

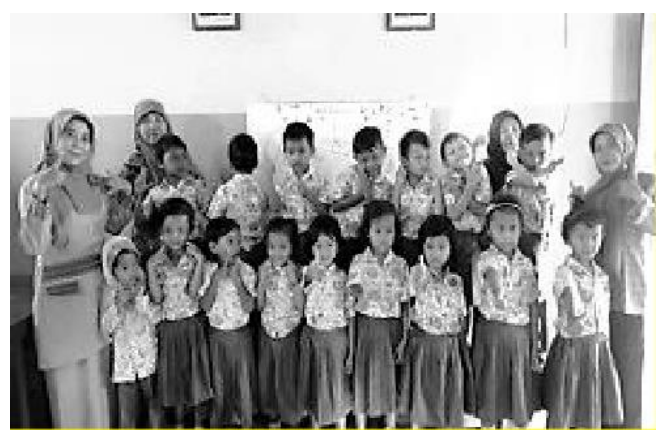

Gambar 7. Silahturahmi dan penyampaian rencana pelaksanaan program

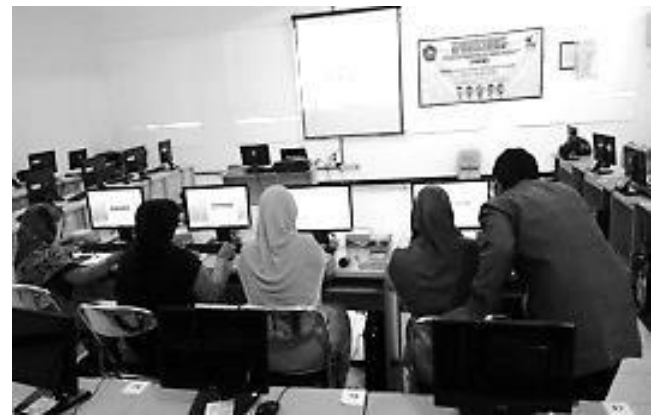

Gambar 8.. Workshop media di laborotarium komputer

Untuk memastikan permasalahan yang terjadi pada kedua lembaga mitra ini, maka dilakukan pengamatan awal dan dilanjutkan dengan diskusi bersama kepala sekolah dari kedua lembaga. Setelah dilakukan wawancara langsung, maka ditemukan fakta-fakta yang berhasil dihimpun berdasarkan informasi dari pengeola kedua TK dan pengamatan lapangan, meliputi:

1. Tenaga pendidik yang mempunyai kualifikasi akademik sebagai guru TK belum memenuhi rasio ideal dengan jumlah anak, untuk BA Aisyiah Bulakrejo 03

2. Pengetahuan teknologi media ajar untuk pembuatan media pembelajaran relatif masih kurang. 
3. Sarana bermain bagi anak untuk alat permainan edukatif (APE) belum mencukupi dan memenuhi kebutuhan bagi setiap anak, baik macam ataupun jumlahnya, sehingga mengakibatkan persaingan/ berebut antar anak untuk mendapatkan APE yang tersedia, sehingga tim mmberikan bantuan sarana dan prasarana bermain APE seperti berikut :

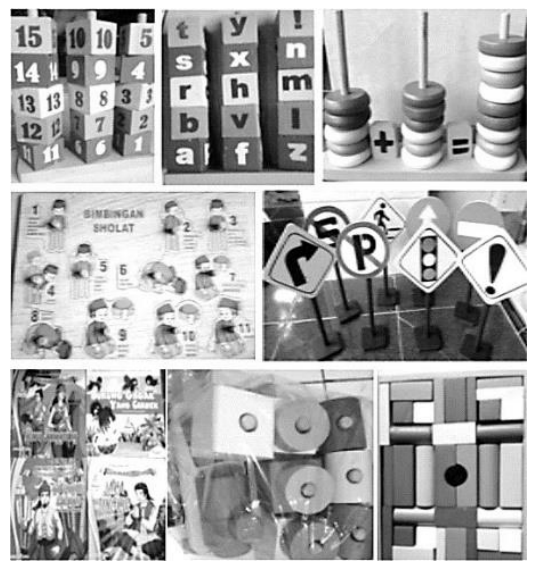

Gambar 9. Beberapa sampel alat permainan edukatif

4. Kekurangan APE dicoba untuk diatasi dengan membuat sendiri, namun tenaga pendidik belum mempunyai keahlian dan pengalaman yang mencukupi untuk memanfaatkan bahan-bahan sekitar sebagai sumber bahan baku pembuatan APE yang berguna sebagai media belajar bagi anak-anak. Dibawah ini adalah foto yang menunjukkan pemanfaatan bahan-bahan alam dan berang bekas ,kardus bekas, papan, triplex, untuk memberikan stimulasi pada anak oleh guru

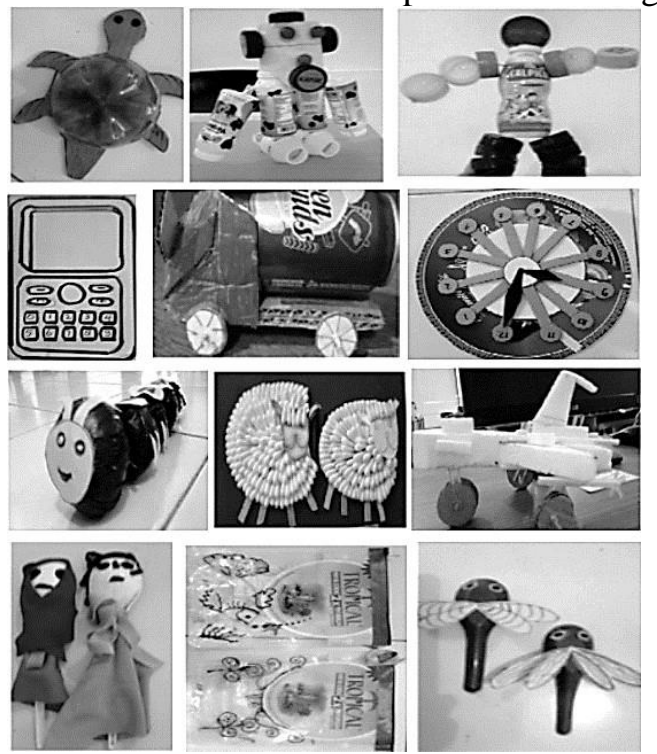

Gambar 10. Alat permainan edukatif bahan bekas

5. Bahan pembelajaran untuk anak - anak belum memenuhi kebutuhan setiap anak dan masih kurang secara kuantitas maupun kualitas. Sebagai contoh adalah minimnya 
buku cerita bergambar dan media pembelajaran berbentuk media visual.

6. Para pimpinan di wilayah pedesaan belum memberikan komitmen maksimal untuk melakukan tindakan dan langkah nyata peningkatan kualitas pelayanan pendidikan bagi taman kanak-kanak, sehingga masalah seperti pembiayaan dan perawatan sarana prasarana di lembaga TK kurang mendapatkan perhatian utama.

7. Penghargaan secara finansial terhadap jasa pelayanan profesional tenaga pendidik TK masih dibawah rata-rata kelayakan upah minimum kabupaten (UMK)

8. Kondisi ruang kelas dan halaman untuk bermain di TK kurang memberikan kenyamanan bagi anak, karena luas ruang kelas dan halaman sempit, sehingga membatasi ruang gerak anak ketika bermain sambil belajar

Berdasarkan analisis situasi di atas, dapat diidentifikasi permasalahan yang dihadapi mitra BA Aisyiah Bulakrejo II dan TK Desa Sidorejo 03 di Kecamatan Sukoharjo adalah sebagai berikut:

a Tenaga pendidik di kedua TK, hanya beberapa yang mempunyai kualifikasi akademik sesuai standar TK, karena belum mampu mengikuti pendidikan secara formal di perguruan tinggi yang menghasilkan guru profesional, akibat biaya pendidikan yang tinggi jika dibandingkan dengan pendapatan guru TK secara rutin.

b. Penyediaan alat permainan edukatif yang berkualitas memerlukan biaya dan anggaran yang cukup besar, sehingga lembaga TK tidak mampu membelinya. Sedangkan jika membuat sendiri, maka memerlukan biaya bahan dan manajemen waktu yang cukup.

c. Kemampuan para guru TK untuk mendesain dan merancang bangun sebuah alat permainan edukatif belum menguasai, dan banyak guru TK yang kurang mempunyai inisiatif untuk melakukannya, akibat kurangnya penghargaan (reward) terhadap apa yang mereka hasilkan

d. Peralatan yang tersedia untuk merancang dan membuat APE dan sarana pelaksanaan workshop pembuatan media ajar tidak ada, sehingga perlu dilakukan kerjasama bagi penyedia sarana, misalnya; laboratorium komputer atau bengkel

e. Keterbatasan dana dan anggaran dari birokrasi setempat mengakibatkan kurangnya alokasi anggaran untuk membantu operasional sehari - hari pada lembaga TK. Hal ini juga akibat ketidak pahaman para pimpinan wilayah setempat terhadap manfaat jangka pendek dan jangka panjang program TK.

f. Biaya operasional yang terbatas berakibat kepada penghargaan finansial yang bisa didapatkan oleh para guru di masing-masing TK. Hal ini seiring juga dengan status non PNS yang dimiliki sebagian besar guru, sehingga mereka hanya bisa mengandalkan pemasukan dari gaji yang diberikan oleh lembaga TK. Sedangkan lembaga TK hanya memiliki sumber pemasukan rutin dari dana iuran orang tua anak yang juga sebagian besar berasal dari kelas ekonomi bawah. Jika lembaga TK mengenakan iuran diatas kemampuan rata - rata ekonomi orang tua anak, maka dikhawatirkan banyak orangtua yang akan mengurungkan niatnya untuk mengembangkan potensi dan bakat anak di lembaga TK.

g. Perencanaan awal yang kurang matang dan anggaran yang minim, ketika mendirikan lembaga TK mengakibatkan rancang bangun sarana dan prasarana untuk mendukung proses pembelajaran dan pengembangan anak menjadi terabaikan, sehingga sering menjadi hambatan pencapaian standar TK yang berkualitas nasional. Untuk itu lembaga TK perlu lebih banyak melibatkan organisasi lain, setingkat Nasional 
maupun Internasional yang menyediakan dana bantuan pengembangan prasarana fisik lembaga TK, namun ternyata hal ini belum diimbangi oleh keluasan akses informasi, kemampuan bernegosiasi dengan pihak lain yang terkait dan keahlian menyusun proposal kerjasama yang saling menguntungkan.

Solusi yang ditawarkan adalah, melaksanakan program pelatihan/ workshop untuk meningkatkan kompetensi guru TK, dalam hal ini pelatihan merancang dan membuat alat permainan edukatif yang berkualitas, inovatif dan kreatif dari sumber daya alam di sekitarnya dan dalam membuat media pembelajaran interaktif dengan media audiovisual. Bahan ajar yang efektif menurut Gerlach dan Ely sebagaimana dikutip oleh Karim (1980) harus memenuhi syarat (1) ketepatan kognitif (cognitive appropriateness); (2) tingkat berpikir (level of shopisication); (3) biaya (cost); (4) ketersediaan bahan (availability); (5) mutu teknis (tecnikel quality). Romiszowski (1986) mengenai pengembangan bahan ajar menyatakan bahwa pengembangan suatu bahan ajar hendaknya mempertimbangkan 4 aspek yaitu : (1) aspek akademik, (2) aspek social, (3) aspek rekreasi, (4) aspek pengembangan pribadi. Jolly dan Bolitho (dalam Tomlinson ed all, 1998), mengajukan langkah - langkah pengembangan bahan ajar sebagai berikut:(1) mengidentifikasi kebutuhan materi yang perlu dibutuhkan, (2) mengeksplorasi kondisi lingkungan wilayah tempat bahan ajar yang akan digunakan, (3) menentukan masalah atau topic yang sesuai dengan kenyataan yang ada di lingkungan peserta didik untuk diajarkan, (4) memilih pendekatan, latihan dan aktifitas serta pendekatan prosedur pembelajaran, dan (5) menulis rancangan materi bahan ajar.

Target yang dihasilkan melalui program PKM ini adalah, sebagai berikut:

1. Membuat 10 jenis alat permainan edukatif yang memanfaatkan potensi bahan baku sumber daya alam dan bahan bekas yang ada di masing-masing wilayah lembaga TK

2. Peningkatan pengetahuan dan keahlian guru dalam membuat media pembelajaran, sebagai sarana mengembangkan materi pembelajaran interaktif bagi anak TK, dengan menggunakan media PPT, animasi, macromedia flash, dan video.

3. Tersedianya jaringan pemasaran secara online melalui website http://peragaedukatif.web.id/web/w p-login.php untuk mempermudah promosi dan penawaran alat permainan edukatif dan teknologi pembelajaran media hasil buatan guru - guru TK kepada pelanggan potensial

Luaran Program PKM, yaitu 1). Pembuatan Alat Peraga Edukatif 10 jenis mainan anak-anak, 2) Pembuatan media pembelajaran, PPT, animasi, macromedia flash dan video bagi guru TK, 3) Publikasi Jurnal ber ISSN, 4) Poster, 5) Publikasi media massa cetak dan online, 6).HAKI Website PeragaEdukatif.web.id dan Haki Peraga Edukatf Bahan Bekas dan Media Interaktif 7). Pembuatan website sebagai jaringan pemasaran online, 8) Buku ber ISBN

\section{METODOLOGI}

\section{a. Tahapan solusi yang ditawarkan}

Upaya untuk mengatasi kesulitan yang dialami mitra, yaitu BA Aisyiah Bulakrejo II dan TK Desa Sidorejo 03, ada beberapa solusi yang ditawarkan yaitu:

1. Memberikan contoh gambar untuk pelatihan/simulasi ataupun melihat youtube cara membuat Alat Peraga Edukatif dari bahan bekas/ bahan- bahan yang banyak ditemukan disekitar lingkungan TK. Sehingga guru mampu merancang dan 
Jurnal SEMAR Vol. 7 No. 2, 2018 hal. 38 - 50

ISSN: 2302-3937 | Copyright (C LPPM Universitas Sebelas Maret

Homepage: https://jurnal.uns.ac.id/jurnal-semar

membuat alat permainan edukatif yang berkualitas, inovatif dan kreatif

2. Memberikan workshop teknologi media ajar interaktif, untuk membuat materi pembelajaran yang menarik, dan website oleh Bambang Eka Purnama, M.Kom dan Trismianto Asmo Sutrisno, ST., M.Kom. Dengan media visual, diharapkan proses pembelajaran menjadi lebih menarik bagi anak-anak. Hasil karya yang dibuat bisa mempunyai nilai jual, bagi pelanggan potensial.

3. Memberikan pelatihan tata kelola website secara bersama yang beralamat di http://peragaedukatif. web.id/web/wp-login.php, sebagai sarana penjualan hasil karya media pembelajaran maupun APE secara online melalui fasilitas internet, pemanfaatan fasilitas media sosial seperti, whatshap, BBM, instagram untuk memperluas akses penawaran hasil karya guru TK. Jika berhasil diharapkan para guru menjadi lebih termotivasi karena mampu mendapatkan penghasilan tambahan, namun tetap bisa menjalankan fungsi utamanya sebagai pendidik TK, dan tidak hanya tergantung honor dari lembaga TK. Sebagai parameter keberhasilan para guru membuat media pembelajaran, diadakan lomba APE dan presentasi media hasil karya guru, untuk meraih juara 1,2,3,4

4. Melaksanakan sosialiasi dengan mengundang orang tua untuk turut berperan aktif dalam mendidik putra putrinya, dihadiri pula lembaga pemerintah desa RT setempat, guru dan tim PKM. Agenda pertemuan juga disertai acara rapat walimurid dan guru, serta penyerahan bantuan sarana prasarana sekolah (meja, kursi, lemari, APE), penyerahan hadiah lomba anak-anak katageri mewarnai dan menggambar, serta hadiah lomba bagi para guru dalam membuat media pembelajaran. Seluruh rangkaian kegiatan PKM sudah terpublikasi di media online: https://sukoharjonews.com/pendidik an/poltekkes-bhakti-mulia-gelarpengabdian-pada-masyarakat/, http://wartabengawan.net/web/pen didikan-danreligi/poltekkes-bhakti- mulia-sukoharjo-terima-hibah-dari- kemristekdikti-gelarworkshop-untuk- pengabdian-masyarakat.html dan media cetak solopos terbit pada Kamis Legi, 26 April 2018 halaman 12. 
Jurnal SEMAR Vol. 7 No. 2, 2018 hal. $38-50$

ISSN: 2302-3937 | Copyright @ LPPM Universitas Sebelas Maret Homepage: https://jurnal.uns.ac.id/jurnal-semar

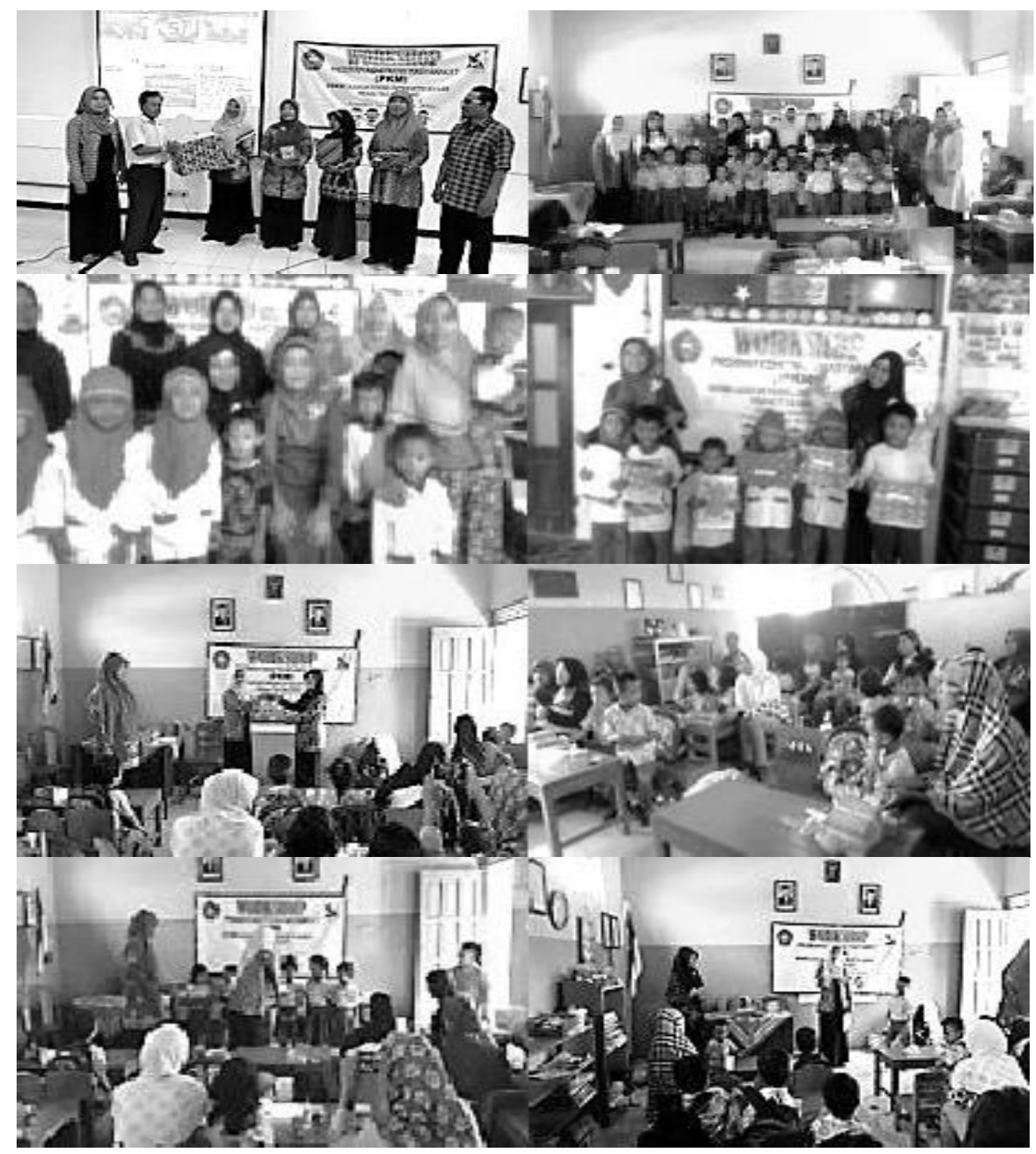

Gambar 11. Penyerahan hadiah lomba, sarana prasarana, temu orang tua guru dan pejabat desa.

5. Secara skematik, solusi yang ditawarkan untuk memecahkan masalah yang dihadapi mitra lembaga BA Aisyiah Bulakrejo II dan TK Desa Sidorejo 03 Kecamatan Sukoharjo disajikan pada gambar 1 . 


\section{b. Metode Pendekatan}

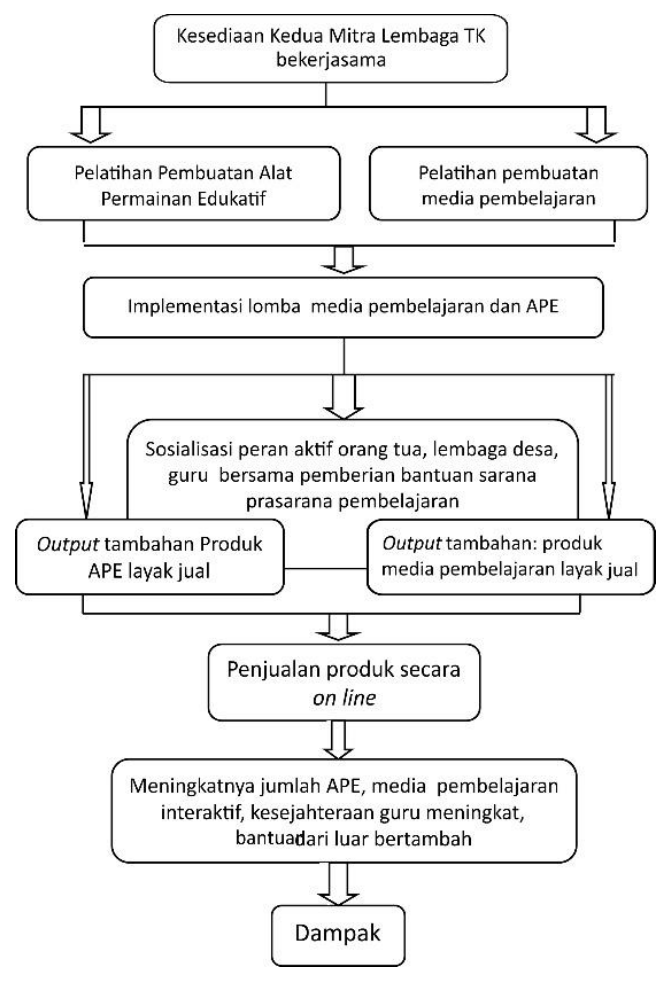

\section{c. Partisipasi Mitra}

Berdasarkan Gambar 12 tampak bahwa, kegiatan partisipasi mitra diawali dengan kesediaan mitra untuk bekerjasama dalam program pelatihan/workshop pembuatan media pembelajaran dan APE, karena menyadari pentingnya kemampuan pedagogik dalam kemajuan SDM lembaga TK. Sosialisasi yang disampaikan pertemuan orang tua, guru dan pemerintah desa adalah berkaitan dengan, sampai sejauh mana orang tua ikut berperan dalam melaksanakan pendidikan usia TK yang berbasis keluarga, sehingga pendidikan anak tidak sepenuhnya tergantung pada guru, serta peran apa saja yang dapat diberikan oleh lembaga pemerintah desa. Sosialisasi dan pertemuan orang tua wali dilaksanakan dalam waktu 1 hari. Melalui sosialisasi tersebut, orang tua anak diberikan pembekalan, bagaimana bisa melakukan pembelajaran di dalam keluarga masing- masing, sehingga dapat membantu memudahkan orang tua untuk ikut aktif mengembangkan potensi dan bakat anaknya. Pelatihan (workshop) diberikan kepada para pendidik di kedua lembaga TK agar mampu membuat model pembelajaran interaktif dan APE sederhana, kreatif dan inovatif menggunakan sumber daya alam dan bahan bekas di sekitar lembaga TK. Materi media pembelajaran interaktif, menggunakan macro media flash, PPT, video, animasi. Pelaksanaan workshop media ajar dilaksanakan di laboratorium komputer Poltekkes Bhakti Mulia selama 5 hari. Anak-anak TK juga berperan aktif dalam kegiatan lomba yang diadakan di sekolah, yaitu lomba mengggambar dan lomba mewarnai sebagai hiburan dan ajang kreativitas anak. Anak-anak juga berlatih memasang puzle buatan guru dan berusaha memasangnya kembali. Sebagai pemenang akan mendapatkan hadiah jura I, II dan III, namun untuk menghindari kecemburuan atau anak menangis, maka yang tidak juara juga diberi hadiah masing-masing 2 buah buku tulis sebagai partisipan. 


\section{HASII, PEMBAHASAN DAN DAMPAK}

Dihasilkan 22 jenis mainan alat peraga edukatif dari bahan-bahan bekas yang ada disekitar, 12 media pembelajaran interaktif. Materi pembuatan macromedia diambil dari buku Cepat dan Mudah Membuat Animasi Kartun dengan Flash. (Andi dan Madcoms, 2016). Flashbook Menciptakan Company Profile dengan Adobe Flash edisi I. (Wibowo, E.H, 2017 dan Membuat Animasi Web Dengan Macromedia Flash Profesional . (Yudhiantoro, Dhani, 2006)

Kegiatan yang sudah dilaksanakan meliputi pelatihan membuat APE dan workshop model interaktif pembelajaran di laboratorium komputer Poltekkes Bhakti Mulia perlu dilakukan evaluasi. Bentuk evaluasi yang dilakukan, misalnya evaluasi pembuatan media IT, dan pengelolaan website. Pendampingan dilaksanakan melalui bimbingan face to face secara berkelanjutan sampai dihasilkan produk berupa Alat Permainan Edukatif (APE), media pembelajaran anak TK. Pembimbingan dan kerjasama dapat melibatkan lembaga atau SDM lain yang kompeten dibidangnya. Pendampingan terhadap pengelolaan website sebagai sarana pemasaran APE dan media secara online antara lain dalam hal mengunggah gambar APE, media materi interaktif, video, ataupun pemberian katalog sebelum diunggah. Adapun dampak segi keuntungan dari kegiatan program ini adalah: a). Workshop APE dan media pembelajaran yang diberikan dapat bermanfaat bagi peningkatan keterampilan dan pengetahuan para guru dalam IPTEK, b). Memberikan kegiatan dan penghasilan tambahan untuk bisa berwirausaha lewat website maupun media internet/online lainnya, apabila karya yanng dihasilkan diminati oleh pelanggan potensial, karena bisa diakses dikalangan luas, c). Meningkatkan keterampilan pedagogik para guru, d). Bantuan sarana dan prasarana yang diberikan sangat membantu lembaga bagi pendidikan anak-anak di TK masing-masing. Sedangkan dampak negatifnya,

\section{KESIMPULAN}

1. Alhamdulillah Program Kemitraan Masyarakat (PKM) sudah berjalan dengan lancar, dan insyaallah ilmu dan teknologi yang disampaikan memberikan manfaat kepada para guru-guru BA Aisyiah Bulakrejo II dan TK Desa Sidorejo 03.

2. Seiring dengan perkembangan jaman dan Iptek, selayaknya cara pembelajaran konvensional untuk anak-anak TK sedikit ada kemajuan dengan adanya pembelajaran dengan media. Supaya proses belajar mengajar menjadi lebih menarik.

3. Para guru yang kreativ untuk mengembangkan ketrampilan membuat APE dan media pembelajaran, akan sedikit mengatasi kesulitan lembaga dalam biaya operasional pembelian mainan dan keterbatasan SDM.

\section{UCAPAN TERIMAKASIH}

Dengan telah selesainya kegiatan Pengabdian Masyarakat dan penyusunan laporan akhir Program Kemitraan Masyarakat ini, terimakasih yang tidak terhingga kami sampaikan kepada pihak-pihak yang telah memberikan kesempatan pengabdi untuk melakukan kegiatan serta telah memberikan bantuan, baik berupa dana, ijin maupun partisipasi.

1. Kemenristek Dikti

2. Unit Penelitian dan Pengabdian Masyarakat Poltekkes Bhakti Mulia

3. Direktur Poltekkes Bhakti Mulia Sukoharjo

4. BA Aisyiah Bulakrejo II dan TK Desa Sidorejo 03 
Jurnal SEMAR Vol. 7 No. 2, 2018 hal. $38-50$

ISSN: 2302-3937 | Copyright @ LPPM Universitas Sebelas Maret Homepage: https://jurnal.uns.ac.id/jurnal-semar

\section{REFERENSI}

Departemen Pendidikan Nasional. 2003. Undang-Undang Republik Indonesia Nomor 20. Tentang Sistem Pendidikan Nasional. Jakarta.

Departemen Pendidikan Nasional. 2014.Undang - Undang Republik Indonesia nomor 35. Tentang Perlindungan Anak.

Gordon and Jeanette Vos. 1993. The Learning Revolution. New Zealand.

Karim, Marlina. 1980. Pemilihan Bahan Pengajaran. Jakarta: Penlok P3G

Andi dan Madcoms. 2016. Cepat dan Mudah Membuat Animasi Kartun Dengan Flash edisi I. Yogyakarta: Penerbit Andi dengan Madcoms

Romisszomski. 1986. Developping Auto Instructional Materials. Piladelphia: Nicolas Publishing.

Syah. 2010. Psikologi Pendidikan Dengan Pendekatan Baru. Bandung: Remaja Rosdakarya.

Tomlinson, B. 1998. Materials Development $\quad$ in Language Teaching United Kingdom: Cambridge University Press.

Wibowo, E.H .2017. Flashbook Menciptakan Company Profile dengan Adobe Flash edisi I. Yogyakarta: Penerbit Andi

Yudhiantoro, Dhani. 2006. Membuat Animasi Web Dengan Macromedia Flash Profesional 8. Yogyakarta: ANDI 